\title{
Caring for the carer in the era of HIV diagnosis
}

\begin{tabular}{|c|c|}
\hline \multicolumn{2}{|c|}{$\begin{array}{l}\text { Authors: } \\
\text { Lempye J. Sempane }^{1} \\
\text { Maake J. Masango }^{1}\end{array}$} \\
\hline \multicolumn{2}{|c|}{$\begin{array}{l}\text { Affiliations: } \\
{ }^{1} \text { Department of Practical } \\
\text { Theology, University of } \\
\text { Pretoria, South Africa }\end{array}$} \\
\hline \multicolumn{2}{|c|}{$\begin{array}{l}\text { Note: } \\
\text { This article is published in the } \\
\text { section Practical Theology } \\
\text { of the Society for Practical } \\
\text { Theology in South Africa. }\end{array}$} \\
\hline \multicolumn{2}{|c|}{$\begin{array}{l}\text { Correspondence to: } \\
\text { Maake Masango }\end{array}$} \\
\hline \multicolumn{2}{|c|}{$\begin{array}{l}\text { Postal address: } \\
\text { PO Box 84173, Greenside } \\
\text { 2034, South Africa }\end{array}$} \\
\hline \multicolumn{2}{|c|}{$\begin{array}{l}\text { Email: } \\
\text { maake.masango@up.ac.za }\end{array}$} \\
\hline \multicolumn{2}{|c|}{$\begin{array}{l}\text { Dates: } \\
\text { Received: } 16 \text { Aug. } 2011 \\
\text { Accepted: } 21 \text { Sept. } 2012 \\
\text { Published: } 24 \text { May } 2013\end{array}$} \\
\hline \multicolumn{2}{|c|}{$\begin{array}{l}\text { How to cite this article: } \\
\text { Sempane, L.J. \& Masango, } \\
\text { M.J., 2013, 'Caring for the } \\
\text { carer in the era of HIV } \\
\text { diagnosis', HTS Teologiese } \\
\text { Studies/Theological Studies } \\
69(2), \text { Art. \#1163, } 5 \text { pages. } \\
\text { http://dx.doi.org/10.4102/ } \\
\text { hts.v69i2.1163 }\end{array}$} \\
\hline \multicolumn{2}{|c|}{$\begin{array}{l}\text { Copyright: } \\
\text { (C) 2013. The Authors. } \\
\text { Licensee: AOSIS } \\
\text { OpenJournals. This wo } \\
\text { is licensed under the } \\
\text { Creative Commons } \\
\text { Attribution License. }\end{array}$} \\
\hline \multicolumn{2}{|l|}{ Read online: } \\
\hline 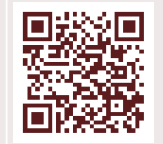 & $\begin{array}{l}\text { Scan this QR } \\
\text { code with your } \\
\text { smart phone or } \\
\text { mobile device } \\
\text { to read online. }\end{array}$ \\
\hline
\end{tabular}

The care of terminally ill patients can be physically, emotionally as well as psychologically exhausting. In the era where everyone is busy with his or her hectic daily schedule, caring for someone diagnosed with HIV on her or his deathbed can be a daunting challenge. Caring for someone dying of AIDS does not only challenge the physical being but rather leaves the carer emotionally drained. What was of concern to the author was to see the struggle that the caregiver goes through whilst caring for the sufferer. More often than not, pastoral care and counselling concentrate mainly on the pain and the suffering of the sick person. In the process, pastoral care loses sight of the agony, the emotional strain and, above all, the trauma of the caregivers in their search for answers as they care for the infected. This scenario has prompted the author to look into the theology of caring with an emphasis on pastoral care of the carers with a view of alleviating their emotional burden in caring for the HIV patients.

\section{Introduction}

The term pastoral care denotes care that the whole church community provides to its members. It is a ministry of the congregation through both its ordained and its lay members. This notion dispels the perception that pastoral care is limited only to those who have been trained to perform certain duties, for example the trained pastor who have received certain training to pastor the emotionally afflicted. The call to pastoral care is inherent in baptism, which is in effect a general ordination of all Christians from which specific ministries evolve. Due to the high prevalence of HIV, Christian communities face significant challenges in providing pastoral support to individuals nearing the end of their life, and to their families. Too often, the pastoral caregiver has accepted a role that is secondary to that of the medical personnel who tend to dominate whilst pursuing restorative and palliative goals. Equally, pastoral caregivers have often misunderstood the fact that their duties are the primarily those of spiritual representatives of the pastoral office. Both these responses reflect an understanding of care giving as a professional service. This clearly demonstrates the unique role of the pastoral caregiver as one nears the end of one's life.

In light of the above, it is imperative that those who offer to provide assistance, especially when a diagnosis of HIV has been made, are supported. As the infected person approaches death, dependency on relationships becomes more significant and sometimes problematic:

It is in this stage that the pastoral caregiver must learn to balance a dying patient's needs to retain autonomy and control over his/her life with realistic requirements of providing care and emotional support. (Smith 1998:105)

\section{Theological concepts of pastoral care}

In order fully to understand the phenomenon of caring for the pastoral caregiver, it is imperative to theologically analyse caring in the following way:

- Ministry to patients with HIV is made difficult by the very nature of the disease, for example, it is deadly, contagious and linked largely to sexual promiscuity (Hoffman \& Grenz 1994:210). For this reason, the attitude of the caregiver becomes important, taking into account the daunting task of caring for the people who have been diagnosed with the HI virus. In the process of caring for the infected, the pastoral caregiver becomes exhausted.

- The theological understanding of caring for infected people by the pastoral caregiver can best be described as a call to love God's inflicted people by assuring them that the dignity of the sufferer is intact even in the very unbearable situation.

- The apostle John coins it perfectly by declaring that, for the pastoral caregiver to be involved in the wellbeing of the sufferer, one becomes the hands and the feet of Christ (1 Jn 3:16-18). In essence, it means that the pastoral caregiver goes beyond the pastoral care duty as well as offering a new theology of caring.

- Lastly, theologically the pastoral caregiver is depicted as a shepherd. The following are attributes needed for one to become a shepherd as described in both the Old and New Testament. 


\section{Old Testament attributes of the pastoral caregiver as a shepherd}

The Old Testament's image of a shepherd is that of leading, guiding, bringing back together the scattered flock and protecting it from possible harm (Is 40:11). He lets them lie in fields of green grass and quite waters (Ps 23:2ff.)

Accordingly, the shepherd, in his or her care of the sheep, is sometimes expected to lay down his or her life for the flock he or she is tending. This expression finds its place in Zachariah's account of the messianic shepherd, whose death leads to the purification of the people (Zch 11:4, 2:10, 13:7-9).

Campbell describes the shepherd as the source of rejuvenation. To rejuvenate the image of the shepherd, Campbell (1981:27) argues that the pastoral caregiver needs to restore to it a much neglected quality, namely courage. Accordingly, the pastoral caregiver thus enters into the pain of someone's suffering (in this case, people with AIDS) by means of caring.

\section{New Testament attributes of the pastoral caregiver as a shepherd}

The New Testament (NT) attributes of the shepherd is that of humility, caring and obedience (Lk 1:52). The shepherd is the one who is prepared to sacrifice his or her life in guiding the flock to springs of life-giving water ( $\mathrm{Rv} 7: 17)$. The NT urges believers to do their work not for pay but from a real desire to serve. They should not try to rule over those who have been put in their care but to be an example to the flock (1 Pt 5:2f.).

In essence, the NT attitudes remind the pastoral caregiver that, through compassion, he or she stands between God and the sufferer. It is this compassion that draws members to offer care and support to others who are vulnerable and broken. By their presence and care on behalf of the community, they are expressions of God's presence.

\section{Concepts of caring in the global village}

After we have carefully analysed the theological aspects of caring, it is equally important to look into the caring of the patients in circular terms. Mayeroff, quoted by Switzer (1989) in his book Pastoral Care Emergencies, define caring in circular terms in this way:

To care for the person in need is to help the particular individual to grow and actualize him or herself. There's a difference between wishing a person well and actually helping the individual. Caring therefore take the form of the former, in that it literally becomes a way of relating to someone that involves development and alleviating his or her situation. (p. 1)

In helping the other person to grow, the carer does not impose his or her direction on the patient but rather allows the direction of the other person's growth to guide what he or she does in order to help determine how the carer respond and what is relevant to that response.

Caring does not happen in a vacuum. Accordingly, Mayeroff admits that, for caring to take place, suitable building blocks are to be in place. The building blocks or the ingredients for caring are referred to in the following way:

- Knowledge: Good intensions do not necessarily guarantee knowledge of the sufferer's situation. In cases where someone is suffering from a life-threatening disease like AIDS, it is important to have knowledge of the diagnosis and, above all, a clear knowledge and competence of the diagnosis in order to respond constructively to the care offered.

- Patience: Caring for someone on his or her deathbed is emotionally draining. It requires the carer to be patient and understanding. The person who has been diagnosed with HIV can sometimes have mood swings which can be emotionally draining for the carer. The patience required by the pastoral caregiver refers not only to time but also to space. It requires a combination of being physically present with the sufferer, speaking or listening, sitting with the patient and sharing in silence or actually withdrawing in order to allow the patient a process of assimilation of thoughts and feelings. All of the above can stretch the patience of the carer to the limits.

- Honesty: Honesty is generally regarded as the cornerstone of any relationship. In a challenging situation, such as where someone has been diagnosed with the HI virus, it is of paramount importance. It has the capability to break the conspiracy of silence between the carer and the patient, thus alleviating the burden of caring. If the patient does not trust the carer, or vice versa, pastoral care and counselling will virtually come to a halt.

\section{Caring in the traditional setting}

Musimbi and Kanyoro (2000) define culture as follows:

A particular people (nation, tribe, ethnic group) has its own culture, its distinct way of living, loving, eating, playing and worshiping. Culture may refer to the musical and virtual arts; modern influences on life, an acquired tradition or to regulations that bind the life of a community ... Culture can be a double edged sword: it can form community identity and it can also be used to set apart or oppress those whom culture defines as other. Participation in culture is so natural and ubiquitous that most people take culture for granted. (pp. 62-63)

In contrast, Surin (1990) defines it as:

a particular way of life, whether of a people, a period, a group or humanity in general. A material production of society which becomes a central system of practices, meanings and values which can properly be called dominant and effective. (p. 36)

In relation to the above definitions, culture or traditional practices seem to be drivers in the era of HIV infection. The patient's cultural background can make or break the relationship between the pastoral caregiver and the patient. For pastoral caregivers to succeed in their quest to be catalysts in the caring of the patient it is imperative that they be adequately empowered in the cultural background of the people that they wish to help.

It is in this way that Louw (1994:21) assert that caring in an African context must be seen as a social and community issue. He argues that, in the traditional approach to caring, the 
individual stands in the centre of a network of relationships. This means that when one person is sick, the community becomes affected. In the case of someone being infected with the $\mathrm{HI}$ virus, the family as well as the community become affected. This is clearly demonstrated by the way African people greet each other. When enquiring, 'How are you?' the 'you' is often in plural form to include everybody at home. Illness and health are thus part of systems thinking. The 'whole' is more important than its parts. Components do not function according to their 'nature' but according to their position in the network (Friedman 1985:15).

For an African person, the process of caring for the sick by the pastoral caregiver plays an important role in the traditional life. The patient will therefore find solace in the fact that someone who stands in his or her situation takes care of his or her condition. For his part, the carer finds satisfaction in caring for the patient, knowing that he or she is acceptable. Mbiti (1969) qualifies this healthy relationship and acceptance in this way:

When he suffers, he does not suffer alone but with the corporate group. When he rejoices, he rejoices not alone but with his king's men, his neighbours and his relative, dead of living. Whatever happens to the individual happens to the whole group. Whatever happens to whole group happens to the individual. The individual can only say 'I am because we are, and since we are, therefore I can. (p. 108)

In biblical terms, Paul summarises this element of caring in this way: 'For we are one body in Christ, if one part is aching, the whole body becomes sick' (1 Cor 12:21-26). This is akin to the African traditional value of $u b u n t u$ [I am because you are], which is doing whatever is necessary to care for the sick person because their sickness affects everyone in the community. By doing so, it will assure that life flows on as normal.

\section{The concept of ubuntu in caring for the patient with HIV}

In many areas where people are afflicted by HIV, community members spend time in a sick neighbour's house, helping with chores, listening and praying with the sick. Although this can be seen as a noble gesture, it can be draining on their resources both physical and emotional and, in turn, could affect the health of the community. In the IsiZulu traditional caring system, a disease is an indication of unhealthy individual or communal life. It is the spiritual and mental pain of the whole group to which the sick person belongs. Care in the IsiZulu sense means helping someone to see themselves as a valuable part of the community and contributing to its life:

In the traditional 'church sense', care is seen as the role of the pastor (hence pastoral care). But 1 Peter 9 makes it clear that all believers are royal priest hood. (Gennrich 2004:46)

This means that every church member has a role to play in alleviating the situation, especially in the era of HIV infection. The church cannot exclude anyone who needs help, especially those living with HIV or AIDS.

\section{Empowering caring caregiver in the era of HIV}

Caring for the terminally ill is always clouded by denial that the pastoral caregiver is facing emotional breakdown. This painful denial results in the persistent resistance amongst the pastoral caregivers towards seeking or receiving help. The carers portray themselves as the 'messiah' coming to alleviate the devastating situation faced by the sufferer. Another way to put this is: 'Pull yourself up by your bootstraps and be selfcontained so that persons in your charge will only witness your strengths.'

Though this is done with good intensions, intending not to show vulnerability, it tends to have long-term negative consequences which may result in spiritual burnout and depression in the carer. These psychological features of the carers make them nearly perfect healers, but it may also stand in the way of their being perfect caregivers. The above scenario leads us to burnout which is the subconscious reaction of the carer to the problem at hand:

Burnout or role-stress make be defined as a syndrome of physical and emotional exhaustion, involving the development of a negative self-concept, negative job attitude, and loss of concern and feelings for the clients. (Pines \& Maslach 1993:33)

Hatfield and Dunkel (1988:259-275) describe the common signs of burnout as chronic exhaustion, nightmares, physical weakness, apathy, vulnerability to all kinds of illness. The critical question which this article seeks to address is how pastoral caregivers are empowered in their quest to become effective pastoral carers who will live up to their perceived expectations?

In response to this cardinal question, Stone (1991) says:

most pastors see themselves as shepherds who are there to do whatever is needed for their flock. It follows that in their minds they are the ones to do the serving, rather than the ones to train others to serve. This tends to make them poor sharers or delegators of the lay pastoral care task. (p. 17)

It should be noted that pastoral caregivers do not behave in this manner because of a lack of confidence in other members of the Christian circle, but they do it subconsciously, motivated by the passion and willingness to travel an extra mile whilst disregarding the consequences. The carers' barrier to lay pastoral care arises out of deep concern for the people they serve. In the course of pastoral care, the pastoral caregiver should realise that lay ministry is not a replacement for the pastor's care but an addition and enrichment to it.

Detwiler-Zapp and Dixon (1982) sum up the pastor's reaction in this way: Crisis situations intensify one's natural desire to act ...
spontaneous, immediate action on the part of the pastor can
unintentionally inhibit those in crisis from using personal
resources, prevent them from calling on available support from
family or friends, and increase their feelings of inadequacy. The
result is an exhausted helper and a discouraged, dependent
person ill-equipped to meet the next crisis. The inclination and 
the ability to act quickly could prevent a pastor from recognizing an opportunity to the talents, life experiences and care giving skills of many church members. (pp. $10-11$ )

This article aims at convincing the pastoral caregiver to recognise that pastoral care should be viewed as a ministry of the congregation which should find its strength in the concept of team care. The New Testament presents life in Christ as a compassionate life lived together as a community (Phlp 2:1-4).

It is this compassion that draws members to offer care and support to others who are vulnerable and broken. By their presence and care of the Christian community, they are expressions of God's presence. Pastoral care giving is fundamentally a ministry of sustaining presence. Both sustaining and presence denote key elements of the relationship. Caring relationships, from a theological perspective, are grounded in God's sustaining love and seek the growth and wellbeing of the care partners. Thus, the focus should be God, who is present and who brings people together in the mist of need.

\section{Emotional support and coping skills of the pastoral caregiver}

It is important for the caregiver, especially concerning an emotional subject such as HIV or AIDS, to re-examine their coping abilities for the sake of their emotional survival in order to continue to journey with the infected. One of the best coping mechanisms in pastoral care is the expression of grief. One of the most difficult moments for pastoral caregivers is when their patient has died, perhaps due to AIDS. The death of the patient may involve a personal loss to the carer, especially when a relationship has developed between them. It is therefore important for the counsellor to grieve and cry without shame in order to release the long bottledup emotions. This has proved to be therapeutic as well as emotionally healing for one to continue with the work.

The following personal experience will help the reader to locate the importance of grief as a coping mechanism for the pastoral caregiver:

'In my early days as a chaplain in the emergency management service, I was dispatched to an MVA (Motor Vehicle Accident) incident to debrief both the emergency personnel who attended to the scene and family members who were present at the scene. I did not have the slightest idea of what I would encounter at the scene apart from debriefing those at the scene. Upon my arrival, I discovered what I had least expected. I have been to MVA scenes before, but this one was most traumatising and emotionally devastating as it reminded me of how I lost my aunt in the same manner. The victim's body was thrown across the road, and we had to close all the lanes in the busy road of Johannesburg. The driver had been decapitated, thrown in the direction of the oncoming direction, the upper torso was in the middle of the road and the lower part of the body was on the other side of the road. What made the situation more traumatic to me, the crew and the family was the length of time it took to clear the scene (removing the decapitated corpse). Legally, we could not remove it as we were waiting for the police to perform all their investigative duties, even if it was unacceptable to leave a human body scattered in that manner. This event haunted and compelled me to search for answers and a methodology for caring for the bereaved. It further compelled me to interrogate my way of doing pastoral care.'

In the process, questions such as the following emerged:

- How do I pastorally journey with the bereaved family towards closure?

- As a pastoral caregiver and a commanding officer at the scene, how do I openly grief in the presence of my juniors and the family which is expecting some sort of consolation from me?

This personal experience laid bare our vulnerability as pastoral caregivers to seek emotional support in events of crisis. The real or imagined notion of being a self-sufficient care deliverer but one who never receives care is clearly idolatrous. This fact is more readily affirmed conceptually than experientially in the parable of the Good Samaritan (Lk 10:30-37). Most of us as pastoral caregivers readily identify with the process of ministering to the person in the ditch and providing for the person's needs. It is not easy to picture ourselves in the ditch of life and needing someone to come along to lift us up.

Lastly, as pastoral caregivers, we do not take delight in our weaknesses just as we do not take delight in caring for others. Pastoral caregivers are aware of the fact that it is precisely in their weaknesses that they gain strength. Paul, one of the NT, pioneers learned and spelled it out in his second Corinthian letter. The thorn in his flesh did not leave although he earnestly sought to be delivered. In the mist of his distress, he discovered that God's grace is sufficient, and he came to the point where he was convinced that it was precisely the presence of the thorn that made him draw on the resources of God that he might otherwise have neglected. The time came when he said, incredibly enough, 'when I am weak then I am strong (2 Cor 12:10).

\section{Conclusion}

Acknowledging the fact that no one is indispensable is the first step of empowering pastoral caregivers. They will begin the process of putting themselves on the emotional scale and acknowledging that they are also fragile, just like their clients.

Brueggemann (2001:87) speaks of grief as a means of bridging private hurt into public expression. It is only through the expression of grief by the pastoral caregiver that hope can be re-kindled. In contrast, Means (2000:148) regard grief as a turning point towards a healing process. For healing to take place and for the sufferer in the case of an HIV diagnosis to reach the stage of acceptance, grief has to be allowed to take its course.

Through their act of compassion, caregivers provide practical comfort and assistance. This is, however, not the ultimate intent of their calling. Rather, acts of compassion should seek to realise the underlying divine purpose. 


\section{Acknowledgements}

\section{Competing interests}

The authors declare that they have no financial or personal relationship(s) that may have inappropriately influenced them in writing this article.

\section{Authors' contributions}

This article has been adapted from L.J.S.'s (University of Pretoria) PhD dissertation, which was completed under the supervision of M.J.M. (University of Pretoria), South Africa.

\section{References}

Brueggemann, W., 2001, The prophetic imagination, Fortress Press, Minneapolis. Campbell, A.V., 1981, Rediscovering pastoral care, Anchor Press, London.

Detwiler-Zapp, D. \& Dixon, W.C., 1982, Parents of the homosexual, Westminster Press, Philadelphia.
Friedman, E.H., 1985, Generation to generation: Family process in church and synagogue, The Guilford Press, New York.

Gennrich, D., 2004, The church in an HIV+ world, Cluster Publications, Pietermaritzburg.

Hatfield, S. \& Dankel, J., 1988, Understanding and working with emotional reaction of staff, Aspen Publishers, Gaithersburg.

Hoffman, G. \& Grenz, S., 1994, Ministry in the midst of an epidemic, Multnomah Press, Portland.

Louw, D., 1994, 'Ministering and counselling the person with Aids', Journal of Theology for Southern Africa 71(June), 37-50.

Mbiti, J., 1969, African religion and philosophy, Heinemann Publication, London. http://dx.doi.org/10.2307/1594871

Means, J.J., 2000, Trauma \& evil, Fortress Publication, Minneapolis.

Musimbi, R. \& Kanyoro, A., 2000, 'Culture' dictionary of third world theologies, Orbis Publishers, New York.

Pines, A.M. \& Maslach, C., 1993, Voices of long term care, Pine Forge Press, Corpus Christi, Texas.

Smith, S.J., 1988, Aids: Living and dying with hope, Paulist Press, New York.

Stone, H.S., 1991, The caring church, Augsburg Publication, Minneapolis.

Surin, J.J., 1990, Evaluating Stress, The Scarecrow Press, London. http://dx.doi. org/10.2307/466306

Switzer, D.J., 1989, Pastoral care emergencies, Paulist Press, New York. 